\title{
The Galápagos Endemic Darwiniothamnus alternifolius (Asteraceae, Astereae) transferred to Erigeron
}

\author{
Alan Tye \\ Charles Darwin Research Station, Galápagos, Ecuador. Current address: Secretariat of the \\ Pacific Regional Environment Programme, P.O. Box 240, Apia, Samoa. alant@sprep.org
}

AвSTRACt. Following molecular phylogenetic evidence that the Galápagos (Ecuador) endemic genus Darwiniothamnus Harling (Asteraceae, Astereae) is biphyletic, with supporting evidence from several morphological traits, the species D. alternifolius is transferred to the genus Erigeron L. as E. alternifolius (Lawesson \& Adsersen) N. Andrus \& Tye.

Key words: Darwiniothamnus, Ecuador, Erigeron, Galápagos.

The genus Darwiniothamnus Harling (Asteraceae, Astereae) was erected in 1962 for two Galápagos endemic species, which Hooker (1847) originally assigned to Erigeron L. To the two original species, D. lancifolius (Hook. f.) Harling and D. tenuifolius (Hook. f.) Harling, a third was added with the discovery of D. alternifolius Lawesson \& Adsersen (Lawesson \& Adsersen, 1987). Two different growth forms were encompassed within the genus as so defined. Darwiniothamnus lancifolius and D. tenuifolius are woody shrubs that usually grow to $1-2 \mathrm{~m}$ in height and occasionally reach $3.5 \mathrm{~m}$, have leaves condensed in terminal whorls with internodes much shorter than half the length of the leaves, a condensed corymbiform synflorescence more or less enclosed within the terminal leaves, and 3- to 6-nerved achenes (Harling, 1962; Lawesson \& Adsersen, 1987). In contrast, D. alternifolius is a perennial herbaceous plant, woody only at the base, reaching up to $50 \mathrm{~cm}$ in height and having alternate leaves not condensed in terminal whorls, with internodes at least half the length of the leaves, a cymiform synflorescence that exceeds the terminal leaves, and with all achenes 2-nerved (Lawesson \& Adsersen, 1987; pers. obs.). The three species were nevertheless considered to belong to a single genus because they possess many ray florets, imbricate phyllaria of unequal length, slightly dimorphic achenes, and an aromatic scent (Lawesson \& Adsersen, 1987). Although Nesom (2000) recognized the differences between D. alternifolius and the two other species of the genus that had been previously noted, Nesom and Robinson (2007) maintained Darwiniothamnus as a monophyletic genus. Darwiniothamnus has always been considered closely related to Erigeron
(Harling, 1962; Lawesson \& Adsersen, 1987; Nesom, 1989), a large genus (s.l., ca. 400 spp.) of mostly herbaceous species within the subtribe Conyzinae (Nesom \& Robinson, 2007; Nesom, 2008).

Harling (1962) suggested that the closest relative of Darwiniothamnus could be among shrubby species of Erigeron endemic to coastal Chile, specifically $E$. fasciculatus Colla (as E. berterianus DC.) or E. luxurians (Skottsb.) Solbrig (as E. litoralis (Phil.) Skottsb.), or any of the six species endemic to the Juan Fernández Islands, $600 \mathrm{~km}$ off the Chilean coast. Lawesson and Adsersen (1987) preferred the latter hypothesis, noting further that D. alternifolius is "even more similar to E. fernandezianus" (Colla) Harling than are the other species of Darwiniothamnus. Johnston (1931) and Nesom (1989), in contrast, suggested that Darwiniothamnus might have their closest relatives in the Northern Hemisphere, with candidates E. crenatus Eastw. and E. socorrensis Brandegee from the Revillagigedo Islands (Johnston, 1931), or two groups of mainly Caribbean and Mexican Erigeron (Nesom, 1989, 2000).

A recent molecular study of the three species of Darwiniothamnus, using nucleotide sequences of the internal transcribed spacers of nuclear ribosomal DNA (Andrus et al., 2009), indicates that Darwiniothamnus is biphyletic, with both northern and southern origins. Darwiniothamnus lancifolius and D. tenuifolius form a monophyletic assemblage that shares a recent common ancestor with the Cuban endemic Erigeron bellidiastroides Griseb. The latter nests with a number of Greater Antillean endemics grouped as Erigeron sect. Microcephalum Nesom (Nesom, 2008). Darwiniothamnus alternifolius shares recent ancestry with Chilean species of Erigeron, forming a clade with E. luxurians and E. fasciculatus (as suggested by Harling [1962] for the other two Darwiniothamnus species, but to which they are not closely related [Andrus et al., 2009]), and nested with Erigeron sect. Meridionales Nesom \& Andrus, which is otherwise composed exclusively of South American mainland species (Nesom, 2008).

While logical nomenclatural assignment of the Darwiniothamnus lancifolius-D. tenuifolius clade 
awaits a fuller revision of the genus Erigeron and its close relatives (Nesom, 2008), these findings require removal of $D$. alternifolius from the genus Darwiniothamnus. This taxon is therefore transferred to:

Erigeron alternifolius (Lawesson \& Adsersen) N. Andrus \& Tye, comb. nov. Basionym: Darwiniothamnus alternifolius Lawesson \& Adsersen, Opera Bot. 92: 10. 1987. TYPE: Ecuador. Galápagos: Isabela Island, Sierra Negra Volcano, NW slope, 700 m, 18 Nov. 1985, J. E. Lawesson, H. Adsersen, B. Nowak, A. M. Velasco, S. Abedrabbo \& A. Tupiza 2452 (holotype, QCA; isotypes, C not seen, CDS).

IUCN Red List category. The species has for some time been listed as Critically Endangered (CR A2ace) (Tye, 2000, in press) according to IUCN Red List criteria (IUCN, 2001), owing to a sharp decline in recent decades due to habitat loss and pressure from introduced herbivores in its only known sites on southern Isabela Island.

Acknowledgments. This note stems from the meticulous phylogenetic study of Darwiniothamnus by Nicole Andrus, whom I thank for her insightful discussions of these species. Nicole's father Gary Andrus provided immense support for the project, including assistance with fieldwork, finance, and equipment, and I dedicate this paper to his memory. Conley McMullen, Javier Francisco-Ortega, Guy Nesom, and Duncan Porter contributed discussion and/or comments on the manuscript. This is contribution no. 1082 of the Charles Darwin Research Station.

\section{Literature Cited}

Andrus, N., A. Tye, G. Nesom, D. Bogler, C. Lewis, R. Noyes, P. Jaramillo \& J. Francisco-Ortega. 2009. Phylogenetics of Darwiniothamnus (Asteraceae: Astereae)-Molecular evidence for multiple origins in the endemic flora of the Galápagos Islands. J. Biogeogr. 36: 1055-1069.

Harling, G. 1962. On some Compositae endemic to the Galápagos Islands. Acta Horti Berg. 20: 63-120.

Hooker, J. D. 1847. An enumeration of the plants of the Galápagos Archipelago, with descriptions of those which are new. Trans. Linn. Soc. London 20: 163-233.

IUCN. 2001. IUCN Red List Categories and Criteria, Version 3.1. Prepared by the IUCN Species Survival Commission. IUCN, Gland, Switzerland, and Cambridge, United Kingdom.

Johnston, I. M. 1931. The flora of the Revillagigedo Islands. Proc. Calif. Acad. Sci. 20: 9-104.

Lawesson, J. E. \& H. Adsersen. 1987. Notes on the endemic genus Darwiniothamnus (Asteraceae: Astereae) from the Galápagos Islands. Opera Bot. 92: 7-15.

Nesom, G. L. 1989. Infrageneric taxonomy of New World Erigeron (Compositae: Astereae). Phytologia 67: 67-93.

- 2000. Generic conspectus of the tribe Astereae (Asteraceae) in North America and Central America, the Antilles, and Hawaii. Sida, Bot. Misc. 20: 1-100.

- 2008. Classification of subtribe Conyzinae (Asteraceae: Astereae). Lundellia 11: 8-38.

\& H. Robinson. 2007. Tribe Astereae. Pp. 284-342 in J. W. Kadereit \& C. Jeffrey (editors), The Families and Genera of Vascular Plants, Vol. VIII. Flowering Plants. Eudicots: Asterales. Springer-Verlag, Berlin.

Tye, A. 2000. Galápagos species accounts. Pp. 33-430 in R. Valencia, N. Pitman, S. León-Yánez \& P. M. Jørgensen (editors), Libro Rojo de las Plantas Endémicas del Ecuador 2000. Herbarium of the Pontificia Universidad Católica del Ecuador, Quito.

. Galápagos species accounts. In S. León-Yánez (editor), Libro Rojo de las Plantas Endémicas del Ecuador, 2nd ed. Herbarium of the Pontificia Universidad Católica del Ecuador, Quito (in press). 


\section{$2 \mathrm{BHL}$ Biodiversity Heritage Library}

Tye, Alan. 2010. "The Galápagos Endemic Darwiniothamnus alternifolius (Asteraceae, Astereae) transferred to Erigeron." Novon a journal of botanical nomenclature from the Missouri Botanical Garden 20, 111-112.

View This Item Online: https://www.biodiversitylibrary.org/item/123332

Permalink: https://www.biodiversitylibrary.org/partpdf/121990

\section{Holding Institution}

Missouri Botanical Garden, Peter H. Raven Library

\section{Sponsored by}

Missouri Botanical Garden

\section{Copyright \& Reuse}

Copyright Status: Permission to digitize granted by rights holder Rights: https://www.biodiversitylibrary.org/permissions

This document was created from content at the Biodiversity Heritage Library, the world's largest open access digital library for biodiversity literature and archives. Visit BHL at https://www.biodiversitylibrary.org. 